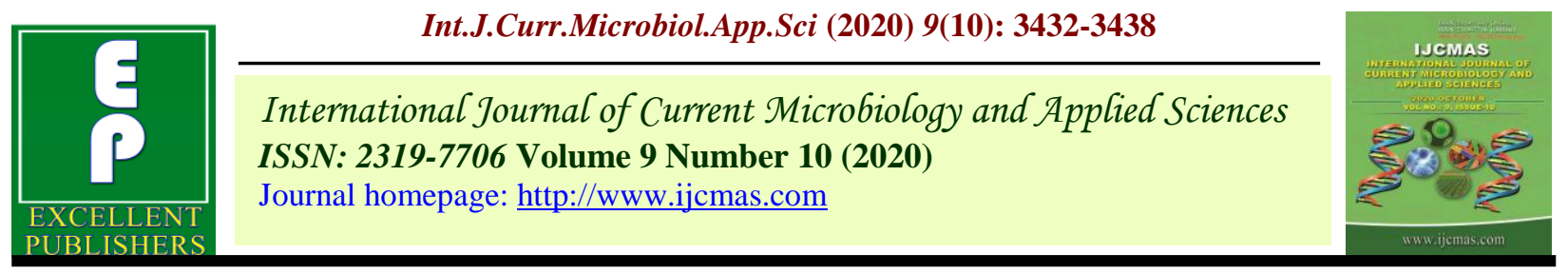

Original Research Article

https://doi.org/10.20546/ijcmas.2020.910.396

\title{
Evaluation of Tomato Genotypes for Growth, Yield and Quality Attributes in Northern Agro Climatic Zone
}

\author{
Komandla Sindhu*, Devi Singh, Vijay Bahadur and Deepanshu \\ Department of Horticulture, Naini Agricultural Institute, Sam Higginbottom University of \\ Agriculture, Technology and Sciences, Prayagraj, India \\ *Corresponding author
}

\section{A B S T R A C T}

Keywords

Tomato, Genotypes, Growth, Yield and Quality

Article Info

Accepted:

26 September 2020

Available Online:

10 October 2020
An experiment on Tomato Genotypes was conducted during November, 2019 to March, 2020 in Research Field, Department of Horticulture, Naini Agricultural Institute, Sam Higginbottom University of Agriculture, Technology and Sciences, Prayagraj (U.P.) India. The results of the present investigation, regarding the evaluation of tomato for plant growth, fruit yield and quality of Tomato Hybrids, have been discussed and interpreted in the light of previous research work done in India and abroad. The experiment was conducted in Randomized block design with 11 Genotypes of Tomato obtained from different sources, were each genotype replicated thrice. From the present experiments it is found that the genotypes $G_{1}$ (Arka Rakshak) found suitable genotypes in terms of growth and yield parameters followed by $G_{2}$ (Arka Vikas), genotype $G_{3}$ (Pusa Ruby) found best for TSS content and minimum vegetative growth, yield and quality was recorded in genotype $\mathrm{G}_{8}$ (Navodaya).

\section{Introduction}

Vegetables are rich and comparatively cheaper source of vitamins. The importance of vegetable crops in India can be judged from the fact that the majority of Indian population is vegetarian. India produces the largest variety of vegetables. Consumption of vegetable provides taste, palatability, increases appetite and provides fiber for digestion and prevents constipation.

Tomato botanically Solanum lycopersicum belongs to Solanaceae family originated in South America, grows in vast sort of environment ranging from tropical to sub tropical areas. Tomato is one of the world's largest cultivated vegetable and known as protective food because of its versatility, special nutritive values and export economy.

Tomato production is affected with various factors like insects, diseases, low yields, crop failures, heat complexes and salinity that need systematic breeding effort. Considering the importance of tomato as a potential vegetable both as domestic consumption as well as export market, it is important to increase its productivity along with desirable attributes through genetic manipulation (Iregna Tasisa 
et al, 2011). In this context it is necessary to identify plant characters or traits important to the development programme.

The present research is conducted to assess the genotypes for growth, yield and quality attributes under northern agro climatic zone. Yield is a complex character controlled by a large number of contributing characters and their interactions. A study of varietal evaluation between different growth and yield characters provides an idea of association that could be effectively exploited to formulate selection strategies for improving yield components. For any effective selection program, it would be desirable to consider the relative magnitude of association of various characters with yield, therefore proper understanding of the genotypes helps in identifying the best genotype for a particular area.

\section{Materials and Methods}

The present Experiment was conducted in Randomized Block Design (RBD), with eleven treatments (Genotypes), replicated thrice with, in the Research field, Department of Horticulture, Sam Higginbottom University of Agriculture, Technology and Sciences, Prayagraj during November, 2019 to March, 2020. Total number of treatments (Genotypes) were eleven viz. $\mathrm{G}_{1}$ (Arka Rakshak), $\mathrm{G}_{2}$ (Arka Vikas), $\mathrm{G}_{3}$ (Pusa Ruby), $\mathrm{G}_{4}$ (PH - 4), $\mathrm{G}_{5}$ (Pusa rohini), $\mathrm{G}_{6}$ (Arka Abhay), $\mathrm{G}_{7}(\mathrm{CO}-3)$ and $\mathrm{G}_{8}$ (Navodaya), $\mathrm{G}_{9}$ (AVTO - 9802), $\mathrm{G}_{10}$ (Arka Samrat) and $\mathrm{G}_{11}$ (AVTO - 1314).

\section{Climatic condition in the experimental site}

The area of Prayagraj district comes under subtropical belt in the south east of Utter Pradesh, which experience extremely hot summer and fairly cold winter. The maximum temperature of the location reaches up to $46^{\circ}$
C- $48^{\circ} \mathrm{C}$ and seldom falls as low as $4^{\circ} \mathrm{C}-5^{\circ} \mathrm{C}$. The relative humidity ranges between 20 to $94 \%$. The average rainfall in this area is around $1013.4 \mathrm{~mm}$ annually. However, occasional precipitation is also not uncommon during winter months.

\section{Results and Discussion}

The present investigation entitled "Evaluation of Tomato genotypes for growth, yield and quality attributes in Northern Agro climatic zone" was carried out during November, 2019 to April, 2020 in Research Field, Department of Horticulture, Naini Agricultural Institute, Sam Higginbottom University of Agriculture, Technology and Sciences, Prayagraj (U.P.) India. The results of the present investigation, regarding the evaluation of different genotypes of Tomato for for growth, yield and quality parameters, have been discussed and interpreted in the light of previous research work done in India and abroad.

The results of the experiment are summarized below.

\section{Growth parameters}

In terms of Plant Height, maximum significant plant height $(39.34,44.35,50.56$ and $58.30 \mathrm{~cm}$ ) at $30,60,90$ and 120 DAS, was recorded in $\mathrm{G}_{1}$ (Arka Rakshak) followed by $\mathrm{G}_{2}$ (Arka Vikas) with $(36.98,42.05,47.04$ and $54.06 \mathrm{~cm}$ ) whereas minimum (26.95, $31.11,34.55$ and $39.04 \mathrm{~cm}$ ) was recorded in $\mathrm{G}_{8}$ (Navodaya). The variability in plant height in different genotypes is due to the suitability of genotypes in climatic condition of Prayagraj and growth characters of genotypes of tomato, these findings correlates with the findings of Naresh et al., (2000), Ahmad et al., (2007) and Asati et al., (2008) in Tomato.

In terms of Number of branches/plant, maximum branch at $(7.35,8.56,10.52$ and 
12.71) at 30, 60, 90 and 120 DAS, was recorded in $G_{1}$ (Arka Rakshak) followed by $\mathrm{G}_{2}$ (Arka Vikas) with $(6.72,7.63,9.54$ and 11.64) whereas minimum $(3.57,4.61,6.35$ and 8.57) was recorded in $\mathrm{G}_{9}$ (AVTO 9802). Variability in number of branches in tomato Genotypes is due to the suitability of particular Genotypes in agro climatic conditions and high growth characters of Genotypes, similar findings also reported by Naresh et al., (2000) and Ahmad et al., (2007) in Tomato.

In Plant spread, maximum Plant spread $\left(2574.59,2876.94,3131.51\right.$ and $\left.3745.06 \mathrm{~cm}^{2}\right)$ at 30, 60, 90 and 120 DAS, was recorded in $\mathrm{G}_{1}$ (Arka Rakshak) followed by $\mathrm{G}_{2}$ (Arka Vikas) with (2305.31, 2565.26, 2792.31 and $3349.09 \mathrm{~cm}^{2}$ ) whereas minimum (1215.88, 1321.03, 1448.67 and $\left.1641.74 \mathrm{~cm}^{2}\right)$ was recorded in $\mathrm{G}_{6}$ (Arka Abhay). Variability in Plant spread in tomato Genotypes is due to the suitability of particular Genotypes in agro climatic conditions and high growth characters of Genotypes, similar findings also reported by Naresh et al., (2000) and Ahmad et al., (2007) in Tomato.

In earliness parameter like, Days to first flowering and days to 50\% flowering, minimum (40.68 and 46.94 days respectively) was found in genotype $\mathrm{G}_{1}$ (Arka Rakshak), followed by $\mathrm{G}_{2}$ (Arka Vikas) with (42.27 and 48.32 days) and maximum days to first and $50 \%$ flowering (52.26 and 59.67 days) was recorded in genotype $\mathrm{G}_{10}$ (Arka Samrat).Variability in days to first and 50\% flowering is due to the earliness of the tomato Genotypes; similar findings also reported by Neiraja et al., (2004), Yama et al., (2006), Gautam, et al., (2013) and Debela et al., (2016) in Tomato.

In early fruit picking for different genotypes minimum (59.30 days) was found in $\mathrm{G}_{1}$ (Arka Rakshak), followed by $\mathrm{G}_{2}$ (Arka Vikas) with
(61.16 days) and maximum days to first Fruit picking (74.32 days) was recorded in $G_{10}$ (Arka Samrat).

Variability in days to first picking of tomato Genotypes is due to the early fruit settings and maturity of the tomato Genotypes; similar findings previously also reported by Naresh et al., (2000), Yama et al., (2006), Ahmad et al., (2007) and Gautam et al., (2013) in Tomato.

\section{Yield Parameters}

In terms of Fruits /cluster and Number of fruits/plant for different genotypes Statistically significant variation was recorded maximum Fruits/cluster and Number of fruits/plant (5.44 fruit/cluster and 26.52 fruits/plant) was found in genotype $\mathrm{G}_{1}$ (Arka Rakshak), followed by $\mathrm{G}_{2}$ (Arka Vikas) with (5.26 fruit/cluster and 23.75 fruits/plant) and minimum fruit/cluster (3.38) and fruits/plan (9.56) was recorded in genotype $\mathrm{G}_{8}$ (Navodaya).

Variability in number of fruit/cluster and per plant of Tomato Genotypes is due to the maximum number of fruit set/plant in a particular tomato Genotypes similar findings previously also reported by Naresh et al., (2000), Shivakumar (2000), Mohanty and Prusti (2002) and Sureshkumara et al., (2017) in Tomato.

In Average fruit weight, maximum fruit weight (97.40 g) was found in $\mathrm{G}_{7}(\mathrm{CO}-3)$, followed by $\mathrm{G}_{2}$ (Arka Vikas) with (86.67 g) and minimum average fruit weight $(57.32 \mathrm{~g}$ ) was recorded in $\mathrm{G}_{8}$ (Navodaya).

Variability in average fruit weight is due to the different fruit size of tomato Genotypes; similar findings previously also reported by Naresh et al., (2000), Shivakumar (2000) and Mohanty and Prusti (2002) in Tomato. 
Table.1.1 Plant height, number of primary branches, plant spread, days to first flowering and days to 50\% flowering of different genotypes of tomato

\begin{tabular}{|c|c|c|c|c|c|c|c|c|c|c|c|c|c|c|c|}
\hline \multirow[t]{2}{*}{$\begin{array}{l}\text { Genotype } \\
\text { symbol }\end{array}$} & \multirow[t]{2}{*}{$\begin{array}{l}\text { Genotype } \\
\text { Name }\end{array}$} & \multicolumn{4}{|c|}{ Plant height (cm) } & \multicolumn{4}{|c|}{$\begin{array}{l}\text { Number of Primary } \\
\text { Branches/plant }\end{array}$} & \multicolumn{4}{|c|}{ Plant spread $\left(\mathrm{cm}^{2}\right)$} & \multirow{2}{*}{$\begin{array}{c}\text { Days to } \\
\text { first } \\
\text { flowering }\end{array}$} & \multirow{2}{*}{$\begin{array}{c}\text { Days to } \\
50 \% \\
\text { flowering }\end{array}$} \\
\hline & & $\begin{array}{c}30 \\
\text { DAP }\end{array}$ & $\begin{array}{c}\text { 60 } \\
\text { DAP }\end{array}$ & $\begin{array}{c}90 \\
\text { DAP }\end{array}$ & $\begin{array}{l}120 \\
\text { DAP }\end{array}$ & $\begin{array}{c}30 \\
\text { DAP }\end{array}$ & $\begin{array}{c}\text { 60 } \\
\text { DAP }\end{array}$ & $\begin{array}{c}90 \\
\text { DAP }\end{array}$ & $\begin{array}{l}120 \\
\text { DAP }\end{array}$ & 30 DAP & 60 DAP & 90 DAP & 120 DAP & & \\
\hline$G_{1}$ & $\begin{array}{c}\text { Arka } \\
\text { Rakshak }\end{array}$ & 39.34 & 44.35 & 50.56 & 58.30 & 7.35 & 8.56 & 10.52 & 12.71 & $2,574.59$ & $2,876.94$ & $3,131.51$ & $3,745.06$ & 40.68 & 46.94 \\
\hline $\mathbf{G}_{2}$ & $\begin{array}{l}\text { Arka } \\
\text { Vikas }\end{array}$ & 36.98 & 42.05 & 47.04 & 54.06 & 6.72 & 7.63 & 9.54 & 11.64 & $2,305.31$ & $2,565.26$ & $2,792.31$ & $3,349.09$ & 42.27 & 48.32 \\
\hline $\mathbf{G}_{3}$ & Pusa Ruby & 30.52 & 35.10 & 39.20 & 44.18 & 6.13 & 7.07 & 8.67 & 10.44 & $2,025.10$ & $2,187.71$ & $2,377.94$ & $2,786.68$ & 44.97 & 52.12 \\
\hline $\mathbf{G}_{4}$ & $\mathrm{PH}-4$ & 29.67 & 34.24 & 38.25 & 43.92 & 6.40 & 7.43 & 9.02 & 10.89 & $1,855.91$ & $2,055.91$ & $2,245.03$ & $2,623.83$ & 46.94 & 53.93 \\
\hline $\mathbf{G}_{5}$ & $\begin{array}{l}\text { Pusa } \\
\text { Rohini }\end{array}$ & 35.66 & 39.80 & 41.36 & 45.95 & 6.02 & 7.08 & 8.72 & 10.93 & $1,818.52$ & $2,006.79$ & $2,175.62$ & $2,578.88$ & 48.21 & 55.58 \\
\hline $\mathbf{G}_{6}$ & $\begin{array}{l}\text { Arka } \\
\text { Abhay }\end{array}$ & 31.32 & 35.30 & 38.95 & 44.49 & 5.65 & 6.80 & 8.60 & 10.72 & $1,215.88$ & $1,321.03$ & $1,448.67$ & $1,641.74$ & 44.37 & 51.60 \\
\hline $\mathbf{G}_{7}$ & $\mathrm{CO}-3$ & 33.42 & 37.75 & 41.13 & 46.60 & 4.52 & 5.49 & 7.25 & 9.44 & $1,664.01$ & $1,854.36$ & $2,045.07$ & $2,417.25$ & 43.49 & 50.43 \\
\hline $\mathbf{G}_{8}$ & Navodaya & 26.95 & 31.11 & 34.55 & 39.04 & 4.97 & 6.08 & 7.53 & 9.67 & $1,488.36$ & $1,622.31$ & $1,779.48$ & $2,104.12$ & 56.67 & 65.62 \\
\hline $\mathbf{G}_{9}$ & $\begin{array}{l}\text { AVTO - } \\
9802\end{array}$ & 32.38 & 36.71 & 40.14 & 45.87 & 3.57 & 4.61 & 6.35 & 8.57 & $1,856.94$ & $1,996.43$ & $2,131.54$ & $2,439.82$ & 45.35 & 53.47 \\
\hline $\mathbf{G}_{10}$ & $\begin{array}{l}\text { Arka } \\
\text { Samrat }\end{array}$ & 34.15 & 37.88 & 42.26 & 48.05 & 6.03 & 7.07 & 8.91 & 11.04 & $2,067.41$ & $2,271.01$ & $2,446.49$ & $2,864.32$ & 52.26 & 59.67 \\
\hline $\mathbf{G}_{11}$ & $\begin{array}{c}\text { AVTO - } \\
1314\end{array}$ & 31.51 & 35.29 & 38.82 & 43.79 & 5.08 & 6.08 & 7.76 & 9.89 & $1,706.82$ & $1,830.07$ & $1,959.49$ & $2,233.27$ & 50.31 & 42.67 \\
\hline \multicolumn{2}{|c|}{ F-Test } & S & S & S & $S$ & S & $\mathrm{S}$ & S & S & $S$ & S & S & S & S & S \\
\hline \multicolumn{2}{|c|}{$\mathrm{SE}(\mathrm{d})$} & 0.853 & 0.985 & 0.945 & 0.898 & 0.195 & 0.186 & 0.204 & 0.202 & 68.880 & 73.249 & 74.670 & 82.049 & 1.510 & 1.536 \\
\hline \multicolumn{2}{|c|}{ C.V. } & 3.175 & 3.240 & 2.815 & 2.352 & 4.197 & 3.388 & 2.965 & 2.347 & 4.509 & 4.369 & 4.100 & 3.840 & 3.947 & 3.565 \\
\hline \multicolumn{2}{|c|}{ C.D. at $5 \%$} & 1.791 & 2.069 & 1.985 & 1.886 & 0.409 & 0.390 & 0.429 & 0.424 & 144.693 & 153.871 & 156.856 & 172.356 & 3.172 & 3.226 \\
\hline
\end{tabular}


Table.1.2 Days to first picking, fruit length, fruit width, fruit diameter, number of fruits/cluster, number of fruits/plant, avg. fruit weight (g), yield/plant, yield/plot, yield/ha and Total soluble solids of different genotypes of Tomato

\begin{tabular}{|c|c|c|c|c|c|c|c|c|c|c|c|c|}
\hline $\begin{array}{c}\text { Genotype } \\
\text { symbol }\end{array}$ & $\begin{array}{l}\text { Genotype } \\
\text { Name }\end{array}$ & $\begin{array}{c}\text { Days to } \\
\text { first } \\
\text { picking }\end{array}$ & $\begin{array}{c}\text { Fruit } \\
\text { length } \\
\text { (cm) }\end{array}$ & $\begin{array}{c}\text { Fruit } \\
\text { width } \\
\text { (cm) }\end{array}$ & $\begin{array}{c}\text { Fruit } \\
\text { diamete } \\
\text { r (cm) }\end{array}$ & $\begin{array}{c}\text { Numbe } \\
\text { r of } \\
\text { fruits/cl } \\
\text { uster }\end{array}$ & $\begin{array}{c}\text { Number } \\
\text { of } \\
\text { Fruits/pl } \\
\text { ant }\end{array}$ & $\begin{array}{l}\text { Average } \\
\text { fruit } \\
\text { weight } \\
\text { (g) }\end{array}$ & $\begin{array}{l}\text { Yield/pl } \\
\text { ant (kg) }\end{array}$ & $\begin{array}{c}\text { Yield } \\
\text { per plot } \\
\text { (kg) }\end{array}$ & $\begin{array}{c}\text { Yield } \\
\text { tones/ha }\end{array}$ & $\begin{array}{c}\text { Total } \\
\text { Soluble } \\
\text { Solid } \\
\left({ }^{\mathbf{0}} \text { Brix) }\right.\end{array}$ \\
\hline $\mathbf{G}_{1}$ & $\begin{array}{c}\text { Arka } \\
\text { Rakshak }\end{array}$ & 59.30 & 6.16 & 5.43 & 14.68 & 5.44 & 26.52 & 83.25 & 2.20 & 66.00 & 61.60 & 5.24 \\
\hline $\mathbf{G}_{2}$ & Arka Vikas & 61.16 & 5.87 & 6.19 & 17.08 & 5.26 & 23.75 & 86.67 & 2.05 & 61.50 & 57.40 & 3.92 \\
\hline $\mathbf{G}_{3}$ & Pusa Ruby & 66.09 & 4.25 & 5.15 & 10.98 & 4.61 & 16.74 & 64.12 & 1.07 & 32.10 & 29.96 & 5.93 \\
\hline $\mathbf{G}_{4}$ & PH - 4 & 68.09 & 4.22 & 4.29 & 12.85 & 4.27 & 21.33 & 71.52 & 1.52 & 45.60 & 42.56 & 4.90 \\
\hline $\mathbf{G}_{5}$ & Pusa Rohini & 70.66 & 5.31 & 5.37 & 14.09 & 4.66 & 17.11 & 67.18 & 1.14 & 34.20 & 31.92 & 5.24 \\
\hline $\mathbf{G}_{6}$ & Arka Abhay & 66.45 & 5.02 & 5.19 & 11.90 & 4.51 & 11.18 & 70.21 & 0.78 & 23.40 & 21.84 & 5.39 \\
\hline $\mathbf{G}_{7}$ & $\mathrm{CO}-3$ & 65.99 & 5.49 & 6.50 & 19.53 & 4.43 & 19.78 & 97.40 & 1.92 & 57.60 & 53.76 & 4.88 \\
\hline $\mathbf{G}_{8}$ & Navodaya & 81.10 & 4.15 & 4.79 & 10.72 & 3.38 & 9.56 & 57.32 & 0.54 & 16.20 & 15.12 & 5.54 \\
\hline $\mathbf{G}_{9}$ & $\begin{array}{c}\text { AVTO - } \\
9802\end{array}$ & 68.54 & 5.60 & 6.01 & 14.26 & 4.23 & 15.35 & 80.84 & 1.23 & 36.90 & 34.44 & 4.80 \\
\hline $\mathbf{G}_{10}$ & $\begin{array}{c}\text { Arka } \\
\text { Samrat }\end{array}$ & 74.32 & 5.18 & 5.67 & 13.35 & 3.74 & 20.25 & 81.52 & 1.64 & 49.20 & 45.92 & 4.30 \\
\hline $\mathbf{G}_{11}$ & $\begin{array}{c}\text { AVTO - } \\
1314\end{array}$ & 57.27 & 5.21 & 5.48 & 13.74 & 4.29 & 16.94 & 71.37 & 1.20 & 36.00 & 33.60 & 5.40 \\
\hline \multicolumn{2}{|c|}{ F-Test } & $\mathrm{S}$ & $\mathrm{S}$ & $\mathrm{S}$ & $\mathrm{S}$ & $\mathrm{S}$ & $\mathrm{S}$ & $\mathrm{S}$ & $\mathrm{S}$ & $\mathrm{S}$ & $\mathrm{S}$ & $\mathrm{S}$ \\
\hline \multicolumn{2}{|c|}{$\operatorname{SE}(d)$} & 1.625 & 0.098 & 0.097 & 0.523 & 0.177 & 1.110 & 4.517 & 0.096 & 2.878 & 2.686 & 0.352 \\
\hline \multicolumn{2}{|c|}{ C.V. } & 2.962 & 2.333 & 2.178 & 4.600 & 4.875 & 7.535 & 7.319 & 8.453 & 8.454 & 8.453 & 8.543 \\
\hline \multicolumn{2}{|c|}{ C.D. at $5 \%$} & 3.413 & 0.205 & 0.204 & 1.099 & 0.371 & 2.332 & 9.489 & 0.202 & 6.047 & 5.643 & 0.740 \\
\hline
\end{tabular}


Fruit yield/plant, fruit yield/plot and per hectare for different genotypes, maximum fruit yield $(2.20 \mathrm{~kg} / \mathrm{plant}, 66.00 \mathrm{~kg} / \mathrm{plot}$ and 61.60 tonnes/ha) respectively was recorded in $\mathrm{G}_{1}$ (Arka Rakshak), followed by $\mathrm{G}_{2}$ (Arka Vikas) with $(2.05 \mathrm{~kg} /$ plant, $61.50 \mathrm{~kg} / \mathrm{plot}$ and 57.40 tonnes/ha), whereas minimum fruit yield/plant, per plot and per hectare $(0.54 \mathrm{~kg}$, $16.20 \mathrm{~kg}$ and 15.12 tonnes/ha) respectively, was observed in genotype $\mathrm{G}_{8}$ (Navodaya). Variability in fruit yield in tomato Genotypes is due to the maximum number fruit/plant and maximum average fruit weight of Tomato Genotypes; similar findings previously also reported by Naresh et al., (2000), Shivakumar (2000) and Mohanty and Prusti (2002) in Tomato.

Fruit length for different genotypes, maximum fruit length $(6.16 \mathrm{~cm})$ was found in genotype $\mathrm{G}_{1}$ (Arka Rakshak), followed by $\mathrm{G}_{2}$ (Arka Vikas) with $(5.87 \mathrm{~cm})$ and minimum fruit length $(4.15 \mathrm{~cm})$ was recorded in $\mathrm{G}_{8}$ (Navodaya). Variability in fruit length of tomato Genotypes is due to the different shapes and sizes of tomato Genotypes; similar findings previously also reported by Asati et al., (2008) in Tomato.

Fruit width for different genotypes, maximum fruit width $(6.50 \mathrm{~cm})$ was found in $\mathrm{G}_{7}(\mathrm{CO}$ 3), followed by $\mathrm{G}_{2}$ (Arka Vikas) with (6.19 $\mathrm{cm})$ and minimum fruit width $(4.29 \mathrm{~cm})$ was recorded in $\mathrm{G}_{4}(\mathrm{PH}-4)$. Variability in fruit length/width of tomato Genotypes is due to the different shapes and sizes of tomato Genotypes; similar findings previously also reported by Asati et al., (2008) in Tomato.

Fruit diameter for different genotypes, maximum fruit diameter $(19.53 \mathrm{~cm})$ was found in $\mathrm{G}_{7}(\mathrm{CO}-3)$, followed by $\mathrm{G}_{2}$ (Arka Vikas) with $(17.08 \mathrm{~cm})$ and minimum fruit diameter $(10.72 \mathrm{~cm})$ was recorded in $\mathrm{G}_{8}$ (Navodaya). Fruit diameter and fruit length jointly contribute to fruit size which ultimately is related to fruit yield. Existence of variability among the Genotypes for fruit size factors (fruit length and diameter) may provide opportunity to select a genotype with desirable fruit size. Variability in fruit diameter of Tomato Genotypes is due to the different shapes and sizes of different Genotypes of Tomato; similar findings previously also reported by Asati et al., (2008) in Tomato.

\section{Quality parameters}

In terms of Total Soluble Solids (TSS) for different treatment combinations, maximum TSS (5.93 ${ }^{\circ}$ Brix) was found in $\mathrm{G}_{2}$ (Pusa Ruby), followed by $\mathrm{G}_{8}$ (Navodaya) with (5.54 ${ }^{\mathrm{o}}$ Brix) and minimum Total Soluble Solids (3.92 ${ }^{\circ}$ Brix) was recorded in $\mathrm{G}_{2}$ (Arka Vikas). Variability in Total Soluble Solids in different Genotypes of tomato is previously also reported by Shivakumar (2000), Singh and Cheema (2005), Singh et al., (2014) and Kumar and Rana (2018) in tomato.

From the present experimental findings it is concluded that the genotypes $\mathrm{G}_{1}$ (Arka Rakshak) found suitable genotypes in terms of growth and yield parameters followed by $\mathrm{G}_{2}$ (Arka Vikas), genotype $\mathrm{G}_{3}$ (Pusa Ruby) found best for TSS content and minimum vegetative growth, yield and quality was recorded in genotype $\mathrm{G}_{8}$ (Navodaya).

\section{References}

Ahmad, F., Khan, O., Sarwar, S., Hussain, A., and Ahmad, S. (2007) Performance evaluation of tomato cultivars at high altitude. Sarhad journal of agriculture., 23( 3): 581-585.

Asati, B.S., Rai, N. and Singh, A.K. (2008) Genetic parameters study for yield and quality traits in tomato (Lycopersicon esculentum Mill.). The Asian J. Hort., 3(2): 222-225. 
Debela, K. B., Belew, D. and Nego J. (2016) Evaluation of Tomato (Lycopersicon Esculentum Mill.) Varieties for Growth and Seed Quality under Jimma Condition, South Western Ethiopia, International Journal of crop science and Technology, 2(2): 69-77.

Gautam, U. S., Negi, R. S., Singh, R., Kaushik, S. S., and Singh, A. (2013) Participatory evaluation of Tomato varieties for commercial cultivation during rainy season under kaymore plateau and satpura hills - agro-climatic zone of Madhya Pradesh. Journal of Agricultural Science., 5(4): 238-241.

Kumar, M. N., and Rana, M. K. (2018) Evaluation of tomato (Solanum lycopersicum L.) genotypes for yield and yield attributing characters in semiarid zone of Haryana. Journal of pharmacognosy and phytochemistry. Vol: 7(1); 1605-1608.

Mohanty and Prusti, A. M., (2002) Screening of tomato hybrids in vertisols of Orissa. Orissa J. Hort., 30(2): 29-31.

Naresh Babu, Venkateshwarlu, P., Verma, R. C. (2000) Comperative performance of tomato cultivars in foothills of Nagaland. Indian journal of Hill farming., 13(1/2):98-100.

Neiraja, G.; Redddy, I.P. and Chiranjeevi, C. (2004). Performance of some promising tomato var. (determinate type) under Southern Telagana condition of A.P. J. of Research ANGRAU (vol.32) (No. 4): 44-47.
Shivakumar, K.C., (2000) Evaluation of tomato hybrids for growth, yield and quality parameters under Bangalore condition. M.Sc. (Hort.) Thesis, University of Agricultural Sciences, Bangalore.

Singh, Harvinder and Cheema, D.S. (2005). Studies on genetic variability and heritability for quality traits of tomato (Lycopersicon esculentum Mill) under heat stress condition. J. of Applied Horticulture. 7(1): 55-57.

Singh T., Singh N., Bahuguna A., Nautiyal M. and Sharma V. K. (2014) Performance of Tomato (Solanum lycopersicum L.) Hybrids for Growth, Yield and Quality Inside Polyhouse under Mid Hill Condition of Uttrakhand, American Journal of Drug Discovery and Development, 4(3): 202209.

Sureshkumara, B., Lingaiah, H. B., Shivapriya, M., and Pavithra, H. B. (2017) Evaluation of Tomato Genotypes for Growth, Yield and Quality Attributes Under Eastern Dry Zone of Karnataka, India ISSN: 23197706 Volume 6 Number 11

Yama R. Pandey, Amar B. Pun and Kalika P. Upadhyay (2006) Participatory Varietal Evaluation of Rainy Season Tomato under Plastic House Condition. Nepal Agricultural Research journal., 7: 1115.

\section{How to cite this article:}

Komandla Sindhu, Devi Singh, Vijay Bahadur and Deepanshu 2020. Evaluation of Tomato Genotypes for Growth, Yield and Quality Attributes in Northern Agro Climatic Zone. Int.J.Curr.Microbiol.App.Sci. 9(10): 3432-3438. doi: https://doi.org/10.20546/ijcmas.2020.910.396 